\title{
Karachi's Performative Charisma: Charisma in the City of Karachi
}

\author{
Saqlain Zaidi* \\ Muhammad Moiz Khan**
}

\begin{abstract}
Some argue that Urban Spaces have souls, bodies and charisma. As per the theoretical framework of Hanson \& Verkaaik, ${ }^{1}$ we will explore the Performative Charisma of Urban Space-charisma in the city-with special reference to Karachi. We will investigate ${ }^{2}$ charisma present in Karachi's crowds, in her daring individuals, in knowledge available in fiction and nonfiction based on Karachi. In the last, we will explore, in the light of literature based on Karachi, if cities have souls, is it sensible to say cities have bodies?
\end{abstract}

Keywords: Karachi, Charisma, Art, Urban-space \& History

*Assistant Professor, Media Studies, SZABIST, Karachi

**Assistant Professor, Department of General History, University of Karachi

1 Thomas Blom Hansen and Oskar Verkaaik, "Introduction - Urban Charisma: On Everyday Mythologies in the City," Critique of Anthropology 29, no. 1 (2009): 5-26, https://doi.org/10.1177/0308275X08101029.

2 Blom Hansen and Verkaaik. 


\section{Introduction}

To be sure, flesh does not make a cityscape. Still, sheared off buildings are almost as eloquent as body parts. ${ }^{3}$ One way to understand urban spaces is to know its resident people, to search the social and cultural values, to understand the power politics as all these give form and appearance to the cityscape and urban environment. ${ }^{4}$ Physical spaces define us in ways we cannot comprehend. Places create certain emotive responses. We experience anxiety in those urban spaces and cities where we find ourselves without memories. So, where there is no emotive connection and no memories, many of the people, do not want to spend their lives at such places where they need to wait for emotive connections take a lifetime to nurture. ${ }^{5}$ When an establishment demolishes Kachhi Aabaadis in Karachi, compels the neighbours to leave their homes within days, an extension in road yields in giving up shared family memories, it raises queries and destabilizes our control over our lives, our capacity to construct our futures. ${ }^{6}$ Those who claim to know the urban world, its significant sites and physical layers, those who show abilities to maneuver and control the urban environment, and those who can create narratives about the city and its people, can thus draw on the latent charismatic potentials of urban life itself. ${ }^{7}$ Some argue that Urban Spaces have souls, bodies and they have charisma ${ }^{8}$ and in alignment with this statement about the urban spaces we will explore the meaning of charisma in the city (Karachi), a charisma in Karachi's crowds, in her extraordinary virtuosities in different areas, in her bold and enterprising individuals, and the exceptional maneuvers and unusual acts the city enables and causes. In the last section of the paper we will explore, in the work's light of fiction, poetry, film and nonfiction books written on Karachi, if cities have souls, is it sensible to say cities have bodies? ${ }^{9}$

3 Stephen Graham, Cities, War, and Terrorism: Towards an Urban Geopolitics, First (Malden: Blackwell Publishing, 2004), https://doi.org/10.1016/B978-0-12-374370-1/00004-5.

4 Setha M. Low, "The Anthropology of Cities: Imagining and Theorizing the City," Annual Review of Anthropology 25, no. 1 (1996): 383-409, https://doi.org/10.1146/ annurev.anthro.25.1.383.

5 Saeed Ur Rehman, "I Imagine and Write in a Locally Grounded Way: Bilal Tanweer," Herald, 2018, https://herald.dawn.com/news/1154015.

6 Durriya Kazi, "ARTSPEAK: THE CITY AS AN IDEA," Www.Dawn.Com, June 18, 2017, https://www.dawn.com/news/1339722.

7 Blom Hansen and Verkaaik, "Introduction - Urban Charisma: On Everyday Mythologies in the City."

8 Blom Hansen and Verkaaik.

9 Blom Hansen and Verkaaik. 


\section{Charisma}

The term "Charisma”, in its original Greek kharisma, means a gift and thus something unique, non-trivial and powerful. In Weber's original formulation, we define charisma as something exclusive, an 'anti-economical principle' accredited to people, who directs the hopes and ambitions of numerous people. No longer is a sociological concept of charisma radically democratized, from a bazaar, to the domains of the arts and politics. The lively social life of charisma stands in interesting conflict with the remarkably rigid conceptualization of charisma in the social sciences ${ }^{10}$.

\section{Spirits, Souls and Charisma of Urban Spaces}

Urban Spaces have spirits, and cities have souls. ${ }^{11}$ Some are treacherous, intimidating, but also seductive; others have exquisiteness and surplus; others again by their dreariness. The thriving fantasmic and mythical qualities of cities and urban spaces are effective realities that shape the behavior, cosmologies and wishes of people in cities, or of those who visit them, imagine them, or describe them in narrative or imagery. So, this term urban charisma means two things: on one hand the charisma of a city as in its 'soul' or mythology in its buildings, infrastructure, the historicity of its sites and its anonymous crowds. There is also charisma in the city. Charisma in the city rests on special forms of knowledge, networks, connectedness, courage and daring that enable individuals - politicians, gangsters, business tycoons and the everyday hustler - to assume leadership or to claim hidden and dangerous abilities and powers ${ }^{12}$.

\section{Karachi: Historical Emergence}

After this fundamental premise, we will move towards our Urban Space, Karachi. From its origins, Karachi has been a city of migrants. The conquest of Sindh in 1843 established Karachi as the administrative capital of the province. Karachi was also the most convenient location for a maritime colonial power. The city developed to serve as 'the port nearest to Europe. It was a military necessity, which put communications in the 1857 Indian War

10 Blom Hansen and Verkaaik.

11 Blom Hansen and Verkaaik.

12 Blom Hansen and Verkaaik. 
of Independence from the north of India with the ports of Calcutta and Bombay in jeopardy. ${ }^{13}$

Since its foundation, Karachi bears the burden of its geography. Its natural port, at the crossroads of the Persian Gulf, East Africa, Central Asia, and India, made its fortunes but also sealed its fate. Since the nineteenth century, it has turned Karachi into an antechamber of Afghan conflicts, exposing its populations to external shocks of high magnitude. ${ }^{14}$

On the eve of independence, Karachi, the capital of Sindh, had a population of about 450,000. Over fifty percent of this population was Sindhi speaking. The other languages spoken by different communities living in the city were, in order of importance, Balochi, Urdu-Hindi, Punjabi, Gujrati, Kutchi, Brahui and Marathi. Fifty-one percent of the population was Hindu, forty-two percent Muslim, 3.5 percent Christian and 1.1 percent Parsi. ${ }^{15}$ It was known as 'Paris of the East' and the 'cleanest city in entire India' and exceptional 'sea beach and bathing places' as per the documents of Second World War. ${ }^{16}$

In physical terms, it divided the city into two: the European city and the native city. The European city comprised the Cantonment, Civil Lines and the Sadar Bazaar. Europeans lived here, and those who served them like Europeanized Indians lived here. Sadar Bazaar was the home of the Parsi and Goan communities and contained retail markets, shops and eating places similar to those in European cities. It also contained social facilities, community centres, clubs and religious buildings belonging to the communities that lived here. ${ }^{17}$

There were churches, mission schools and Parsi institutions in Karachi. People celebrated Christmas, Nauroze and May balls. The city had wide roads and open spaces. The native city was close to the port and comprised the old pre-British town and its suburbs. Hindu and Muslim merchants and the working classes dominated it. It contained most of the wholesale markets of

13 Haimda Khuro, "The Making of Colonial Port," in Karachi: Megacity of Our Times, ed. Hamida Khuro and Anwer Mooraj, 1st. (Karachi: Oxfor University Press, 1997), 27-61.

14 Laurent Gayer, Karachi: Ordered Disorder and the Struggle for the City (India: Harper Collins, 2014), 20.

15 Arif Hasan, "The Growth of a Metropolis," in Karachi: Megacity of Our Times, ed. Hamida Khuro and Anwer Mooraj (Karachi: Oxford University Press, 1997), 171-95.

16 Gayer, Karachi: Ordered Disorder and the Struggle for the City, 17.

17 Hasan, "The Growth of a Metropolis." 
the city (such as the Dhan Mandi and Khajji Market) and numerous Hindu temples, Dharamshala, mosques, imambarahs and shrines. The colonial city of Karachi developed from the old native city with its twin quarters of Kharadar and Mithadar. The old city lived alongside the new one and was the heart of the native business life. It had housed the rich 'banias' who had had their worldwide trade based on the hundie which could provide easy credit to the merchant or traveller anywhere in the world. ${ }^{18}$

Karachi remained a city of migrants and an important commercial hub, which provides Pakistan with a window on the world. When Sir Charles David Napier reached the port of Karachi in 1843, he discovered the door of "salted water" (kharadar), giving access to the Arabian Sea and the door of "sweetwater" (mithadar), facing the Lyari river. By 1961, migrants, Pakistanis born outside Karachi amounted to $56 \%$ of the entire population of the city. In the following years, Karachi continued to attract outsiders in large numbers. These newcomers were Punjabi and Pashtun labourers, who came to Karachi because they attract to its vibrant industrial sector. ${ }^{19}$

Post-Partition, Karachi also became Pakistan's industrial centre, and, its workforce was the working-class Urdu speaking Muslim immigrants from India. Karachi's demographics continued to change in the 50s and 60s, and the city became multi-ethnic. While Balochi workers were already present in the city at Partition, Pathans from the North-West Frontier Province also migrated to Karachi in the 50s and 60s, and so did the Punjabis in the 1960s. The Pathans major work was construction, and they had control over the transport business in Karachi as part of state patronage during Ayub Khan's regime (1958-69). The 1998 census shows the following population breakdown in terms of mother tongue: Urdu, 48.52 percent; Punjabi, 13.94; Pushto, 11.42; Sindhi, 7.22; Balochi, 4.34; Seraiki, 2.11; and others, which include speakers of Bengali, Gujarati, and Brahui, are 12.4 percent. ${ }^{20}$

In recent years, over 300,000 Pashtuns migrated from the north-west because of the combat between the army and the Taliban or by the 2010 floods, has altered this ethnic equilibrium to the detriment of Mohajirs. However, Karachi's exact demographic profile remains a matter of

18 Hasan.

19 Gayer, Karachi: Ordered Disorder and the Struggle for the City, 24.

20 Lubna Nazir Chaudhry, "Reconstituting Selves in the Karachi Conflict: Mohajir Women Survivors and Structural Violence," Cultural Dynamics 16, no. 2-3 (2004): 259-90, https://doi.org/10.1177/0921374004047751. 
controversy without reliable census data. This uncertainty has been making the fortune of ethnic leaders, who deploy their numeral imagination and instil in their followers a sense of power in numbers. This is how the leader of the Shahi Syed of Awami National Party (ANP) in Karachi, has claimed the number of Pashtuns in the city approaches four million, which would amount to nearly 20 percent of Karachi's total population. ${ }^{21}$

\section{Karachi's Performative Charisma: Charisma in the city}

The Performative Charisma, one deals with Charisma in the city, charisma that we see in the quintessential urban figures - artists, cab drivers, police or those belonging to popular world - may be charismatic because of their activities and the knowledge and capitals in the city it rumors them to command. ${ }^{22}$

\section{Karachi as the protagonist in Visual Art}

Someone can see charisma in the city (of Karachi) in the works of visual artists, poets, writers whose gift it is to know the city and to act, with style and without fear. For an artist, the city reveals itself. Karachi offers treasures of inspiration to the artists. Such inspirations remain available on the streets, in its buildings and its people. Arif Mahmood, Athar Jamal, A.Q. Arif, are busy documenting its people and places through their mediums and others such as Munawar Ali, inspired by the mood of the city and its activities. ${ }^{23}$

\section{Karachi itself as Art}

The charisma in the city is the manifestation of seeing the city itself as art. The metal and wood markets in Karachi with their systematized stacks of wood or ball bearings, the delicate repousse of the copper workers of Golimar, the stacked circles of paan leaves of the paan mandi, the conical forms of masalas and powdered food colour in Jodia Bazaar, the dyeing vats of dupatta gali, and the riotous decorated commercial vehicles. Karachi addresses to its dwellers beyond sensory delight through the darker and more thought-provoking poetics of the city: Areas with suggestive names like

21 Gayer, Karachi: Ordered Disorder and the Struggle for the City, 26.

22 Blom Hansen and Verkaaik, "Introduction - Urban Charisma: On Everyday Mythologies in the City."

23 Durriya Kazi, "The City as a Canvas," www.dawn.com, 2017, https://www.dawn.com /news/1309996. 
Khamosh Colony, Geedar Colony or Kati Pahari. Karachi's walls have served as a people's newspaper for years, announcing political gatherings, a new product on the market, a spiritualist who can ensure you marry the person of your choice, messages for or against a political personality ${ }^{24}$.

\section{Karachi itself as an Idea}

We can also see the city as an 'Idea' in the parceling of cultural spaces in Karachi: once privileged city dwellers were called "Society" people since PECHS society housed civil servants of grade 17 and above. Today people call them "yeh Clifton aur Defence ke loag." Teen Talwar is a divider between 'them' and 'us.' There may be richer people living in Ranchore Lines or Lyari, but the architecture defines the perception of elitism. Housing areas in Karachi are divided into the housing "society" which implies a consensus to dwell together; the "colony", suggesting an intuitive gathering like a colony of bees or ants - Geedar Colony, Machar Colony, Khamosh Colony. To this has been added an aspirational space housing the mobile - the Gulshan and Gulistan, full of possibilities for a change of circumstances. ${ }^{25}$

\section{Do cities have bodies? ${ }^{26}$}

If cities have souls, can it also be said cities have bodies? There are perhaps two good reasons to explore the notion of cities as bodies. First, people might sense a bodily intimacy with particular urban spaces that go beyond the mere fact that being in a city also implies a physical experience. ${ }^{27}$ This is witnessed by poet Shaikh Ayaz in Karachi. In his poem "Heartache City" he addresses Karachi directly as "O shining, twinkling Karachi, You are no stranger for me", " $O$ bride-like city ", " No matter how vast you become, You would remain in my heart." 28

Second, the physical nearness of the city-or parts of the city-may generate a fantasy of the city as a presence that transcends the notion of the city as a mere physical site. Poet N.M. Danish seems to talk to the city as if he is talking to a friend whom he and others love, sympathize with or are having a row

\footnotetext{
Kazi.

5 Kazi, “ARTSPEAK: THE CITY AS AN IDEA.”

26 Blom Hansen and Verkaaik, "Introduction - Urban Charisma: On Everyday Mythologies in the City."

27 Blom Hansen and Verkaaik.

28 Shaikh Ayaz, "The Heartache City," in Look at the City from Here: Karachi Writings, ed. Asif Farrukhi (Karachi: Oxford University Press, 2012), 120-22.
} 
with. He is addressing Lyari that "You are still sleeping, Time has walked away trampling you, But you go on sleeping". 29

In the history of Pakistani cinema, filmmakers have been dealing with narratives and songs that address Charisma in the city. Lyricist Tanvir Naqvi and director Khawaja Khursheed Anwar made characters talk to the city in Chingari (Spark) in 1964. One can see the Charisma in Karachi in the song "Ae Roshaniyo en Ke Sheher Bataa". This song is proof of the music and lyrics' ability to render and share emotions in a more profound manner than mere romantic love. The rendition is a 5-minute dissection of local culture captured at a mercurial moment of transformation. It is a fabulous but ultimately distressing statement. The final point of interest in this song is that it treats us to a glimpse of what Karachi looked like in the early 1960s. A city where European movies were screened and where the luxury hotels ruled the night with their glitzy lobbies, halls and nightclubs. This song was 'Criticism' on the 'Daur' (Times) of the military dictator Gen. Ayub Khan

Oh city of lights tell me/ there is unease and emptiness There is poverty there is bad deeds/ this new culture is a spark a river of fire burns all around/how did this happen/tell me, oh city

The film's message is that Pakistani society is being overrun by devilish puppets in the form of loose lustful women obsessed with dancing drinking and fornicating. ${ }^{30}$ These expressions are hinting at the sensations that may have something to do with the way urban spaces leave their traces on human bodies, make a mark in the memory or unconscious of human beings through repeated sensory stimuli. The flood of light at night, the ear-piercing noise of mid-day traffic, the perplexing mixtures of smells in bazaars and other public spaces, or the density of human crowds always remain overwhelming for a visitor, a migrant or for a newcomer in the city. ${ }^{31}$

Karachi becomes a dynamic and living entity in Bilal Tanweer's novel "The Scatter Here Is Too Great". Charisma in Karachi here takes this form in the words of a character in the novel and he writes that in Karachi from the salespersons, retailers, sound of automobiles to sounds of ordinary things

29 N.M. Danish, "Lyari," in Look at the City from Here: Karachi Writings, ed. Asif Farrukhi (Karachi: Oxford University Press, 2012), 186-89.

30 Nate Rabe, "Ae Roshniyon Ke Shahar Bata," Lolly Pops - dailylollyblog.wordpress.com, 2017,https://dailylollyblog.wordpress.com/2017/03/08/ae-roshniyon-ke-shahar-bata/.

31 Blom Hansen and Verkaaik, "Introduction - Urban Charisma: On Everyday Mythologies in the City." 
are always there chasing you. The best advice one have if one is on Karachi's roads is Insulation. Try not to see much, try to hear even lesser than seeing and do not touch anything. No matter how invasive any influence is there around, the beauty is to detach yourself from any such influence. ${ }^{32}$

Such impressions are difficult to forget or be indifferent to and often morph into a strong dislike or deep attachment. The city penetrates one's body and structures bodily functions so much that city-dwellers visiting the countryside may have difficulty sleeping in complete darkness and silence ${ }^{33}$. Poet N.M.Danish records such a scenario in these words. You have no idea / Time has moved on. / The small stream / which flowed / before your door / Has turned into a sea. / Do you know how vast is the sea? I What do you know? / If you ever have the leisure to go out your cell / only then you may see. And now on its chest / Roads, tall buildings, / Mobs and politics, / Blood, light, dreams, / Riots, slogans, / A world of violence and hatred thrives / But where are you? ${ }^{34}$

Cities are often gendered. In the collective fantasy of the inhabitants of Karachi, for instance, their city is definitely female in relation to the much more masculine city of Islamabad. This has everything to do with gendered representations of the dominant ethnic groups in both cities-Muhajir and Punjabis respectively and cities are, in a Durkheimian sense, anthropomorphic totems of self-representation. These imaginaries enable Karachiites to be ashamed of their city (for the way it has been 'raped' and 'molested' by recent migrants and indifferent administrators), its capacity to survive and its refusal to surrender. Karachi may be a girl but not a submissive one. ${ }^{35}$

A few years before her premature death in a car accident, the poetess Perveen Shakir (1952-1994) published a 'tribute' to her natal Karachi. Far from celebrating the city, though, these verses are saturated with anger, comparing Karachi with a worn-out prostitute used and abused by all those she gives herself to Karachi ... By God, / This city of mine / Is a whore, / With whom every eligible male, / Descending from the mountains / Or emerging from

32 Bilal Tanweer, The Scatter Here Is Too Great (EPub Edition) (London: Harper Perennial, 2015), https://www.scribd.com/read/234028805/The-Scatter-Here-Is-Too-Great\#n_ search-menu_726946.

33 Blom Hansen and Verkaaik, "Introduction - Urban Charisma: On Everyday Mythologies in the City."

34 Danish, "Lyari."

35 Blom Hansen and Verkaaik, "Introduction - Urban Charisma: On Everyday Mythologies in the City." 
the plains, / With wallets of different sizes, / Spends the night. / In the morning, / Slapping her on one cheek / He expects the other one, / And leaves for work / Drunk in anticipation / Of the night to come. ${ }^{36}$

Parveen Shakir's rage and her own metaphor of the city-as-prostitute are not directed at the city herself but at her residents, especially migrant workers from the Punjab, interior Sindh and the Pashtun Belt, who came in large numbers to the city since the 1960s. Shakir empathises with Karachi, against her 'clients'. At first sight, her indignation seems less related to the mere presence of these migrants in Karachi than to their reluctance to return the favours to their whore of a city. This appears to be neither a class nor an ethnic problem, but one of urban citizenship. In their multi-vocality, these verses remain one of the most powerful evocations of Karachi's recent history and of the role of migration, internal and transnational, in it. 'They eat the city, but they don't feed it', an official of the Karachi Development Authority (KDA) thus told anthropologist Oskar Verkaaik. ${ }^{37}$

\section{Political Aspect}

If, however, we can imagine that cities as bodies or cities having a body, it can also depict them as being ill, as being attacked by disease-bringing vermin or as being in need of surgery. ${ }^{38}$ Politically, the charisma in Karachi gained a different form because of an ongoing process of large-scale urban destruction, not only carried out under the name of urban planning, but disorder, violence and ethnic conflict spoil the healthy nature and future of the city. ${ }^{39}$

From partition time till recent past the major issue that changed the whole charisma in Karachi is the violence of last three decades that somehow became synonymous with Karachi. It is customary to frame the contemporary phase of the armed violence in Karachi, beginning in 1985, in the military's reign dictator Zia-ul-Haq (1977-88), and extending into the

36 Perveen Shakir, "Karachi," in Look at the City from Here: Karachi Writings, ed. Asif Farrukhi (Karachi: Oxford University Press, 2012), 39.

37 Gayer, Karachi: Ordered Disorder and the Struggle for the City, 22.

38 Blom Hansen and Verkaaik, "Introduction - Urban Charisma: On Everyday Mythologies in the City."

39 Graham, Cities, War, and Terrorism: Towards an Urban Geopolitics. 
present as an ethnic conflict, which then produced a sectarian religion-based, offshoot, culminating in the post-9/11 hotbed of terrorism. ${ }^{40}$

It is also customary to frame this violence, in its various permutations, as oppositional to the project of modernity represented by processes of industrialization, urbanization, and the formation of a democratic nationstate. However, as Bowen reminds us, 'ethnic thinking in politics is a product of modern conflicts over power and resources and not an ancient impediment to political modernity'. ${ }^{41}$

"The City of Lights" 42 somehow made to become an urban space with a murder rate as high as 13.49 per 100,000 in 2012. The city of 18 million residents is frequently a victim to conflict and insecurity caused by politically motivated targeted killings, terrorist and gang-related violence and everyday crimes (burglaries, robberies, muggings, kidnappings, vehicle snatching). The violence is there because of several reasons: there is a competition between different violent groups to have the maximum of the pie of Karachi's resources; vicious and forceful strategies like land grabbing, evictions and settlements used by violent armed wings of political groups to gain a hold on constituencies; a political approach to interrupt the economic flows from the city to pressurize the national economy to cut a deal with the federal government. 43

This violence impacts people of every walk of life. Poets share this appearance and form of Karachi in their discourses using powerful metaphors. In his poem I'm Alive and So is My City, poet Harris Khalique laments the pain and loss the city of Karachi has been experiencing in the last three decades. Karachi has been experiencing in the last three decades. He says "Let's mourn and celebrate Karachi", "Mourn the streets that caved in under avarice and mediocrity", "Mourn the libraries that were never opened", "Mourn the cinema halls that were closed down", "Mourn the death inflicted on its citizens", "Let's cry for all who are dead and Let's sing for everyone who is alive". ${ }^{4}$

40 Chaudhry, "Reconstituting Selves in the Karachi Conflict: Mohajir Women Survivors and Structural Violence."

41 Chaudhry.

42 Rabe, "Ae Roshniyon Ke Shahar Bata."

43 Sobia Ahmad Kaker, "Enclaves, Insecurity and Violence in Karachi," South Asian History and Culture 5, no. 1 (2014): 93-107, https://doi.org/10.1080/19472498.2013.863016.

44 Harris Khalique, "I'm Alive and So Is My City," in Look at the City from Here: Karachi Writings, ed. Asif Farrukhi (Karachi: Oxford University Press, 2012), 243-44. 
Here is poet Omer Tarin's comment that shows what people were going through in Karachi and despite loving the city the charisma in the city compelling artists to write heartbreaking expressions like "Urban warfare, Six more die, Karachi cries", "Some still say, We are quite well, thank you, And going to be an Asian Tiger, A stuffed one I am sure". 45

Contemporary Pakistani fiction has also documented the impacts of violence and how contemporary urban mythologies and geographies of fear have ruined the charisma in the city of Karachi. While showing his deep attachment and understanding of the Karachi, Bilal in his debut novel, wrote if you are living in Karachi it means you have developed a strange connection with the violence and the news of the violence. Residents of Karachi anticipates news of violence, remain afraid of it and when they see it has occurred, they want to ignore it because they know there was nothing they could do to stop it. One cannot even grieve if living in Karachi because this city was full of bottled-up grief." 46

\section{Karachi Mass Transit in Pakistani Novel and in Reality}

In the first decade of twenty-first century, nothing else changed the charisma in Karachi more than the sights of flyovers and underpasses in Karachi. Mustafa Kamal, City Nazim (mayor) between 2005 and 2010 committed much of his time and energy to the alleviation of Karachi's structural transport problem. This issue has a particular resonance in Karachi, where everyone remembers the spiral of violence ignited by Bushra Zaidi's death in a traffic accident, and where the creation of a mass transit system has been a matter of debate since the first attempts at urban planning conducted in postcolonial Karachi in the early 1950s and later Mass Transit Programs as discussed by Arif Hasan. ${ }^{47}$ 'Mass Transit', in Karachi, is not merely a matter of concern for urban planners and commuters in a hurry, but also for poets and novelists concerned with the human fabric of their city, as exemplified by Maniza Naqvi's acclaimed eponymous novel. She published Mass Transit in 1998 and tells the story of Safina, a young woman recently returned to Karachi after a long stay abroad. The city which she confronts is both buoyant and chaotic, torn apart by spasmodic outbursts of violence. And for Safina, Karachi's problems come up to one key issue-its lack of a mass transit

45 Khuro, "The Making of Colonial Port."

46 Danish, "Lyari."

47 Gayer, Karachi: Ordered Disorder and the Struggle for the City, 270. 
system. And so Karachi became a City of flyovers: forty-six were commissioned between 2001 and 2012. Karachi's upper and middle classes were Jubilant: they could now drive across the city - to visit friends, relatives or clients, for instance by bypassing 'tension-prone areas'. Whereas the Safina of Mass Transit dreamt of de-compartmentalizing transport across Karachi, the promoters of the 'world class city' fantasies about tension-free corridors linking 'safe rings' by bypassing 'high risk' areas. ${ }^{48}$

\section{Conclusion}

The case of Karachi shows that the relative weakness of state organizations in terms of their ability or willingness to plan the city, or to ensure a uniformly enforced system of property rights, led to divergent societal and political responses. The reliance on kinship-based solidarity allowed some migrant cohorts to sustain and then eventually to regularize unplanned settlements. ${ }^{49}$ Keeping in mind Gazdar and Mallah's opinion charisma in Karachi direly needs caretakers who could feel what Karachi has been going through the way poet, Zeeshan Sahil laments in his poem Granny's Theory. ${ }^{50}$ Granny says: / The world is balanced / on a cow's horn. / When it gets tired / of carrying the whole world / On its horn, / The cow shifts the world / to the other horn.

And like Granny / We are worried / That when the cow / shifts the world / From one horn to the other / Why does our Karachi / Always gets jolted?

In last it would apply to add that the Banksy inspired 'Rang de Karachi' team sprayed stencils for peace on the city walls in 2010 staying one step ahead of the police. Started in 2007, its real effect on the streets of Karachi came in 2016 with the (Re) Imagining Walls of Karachi project that painted murals all over Karachi. It was intended as a social cohesion effort, and text and political imagery were not allowed. These artworks were a better replacement of hate messages previously available on the walls. Artists conceived these artistic renditions on the walls as the only medium to communicate with silent people of the city. ${ }^{51}$

48 Gayer.

49 Haris Gazdar and Hussain Bux Mallah, "Informality and Political Violence in Karachi," Urban Studies 50, no. 15 (2013): 3099-3115, https://doi.org/10.1177 /0042098013487778.

50 Zeeshan Sahil, "Granny's Theory," in Look at the City from Here: Karachi Writings, ed. Asif Farrukhi (Karachi: Oxford University Press, 2012), 241-42.

51 Kazi, "The City as a Canvas." 
As Nathan Blanchard has suggested in his review of Tanweer's novel that being exposed to multiple perspectives is a redemptive way of surviving contemporary life: 'You see, my son, a city is all about how you look at it,' he says, looking at me. 'We must learn to see it in many ways, so that when one of the ways of looking hurts us, we can take refuge in another way of looking. You must always love the city."'52

The conclusion is we need a representation of Karachi in cultural and political arenas that could create such a mental, aesthetic, physical and political ambience in which the citizens experience charisma in the city at its best like Tanweer's descriptions of the city in his novel are tinged with an affectionate familiarity, like someone talks about a close friend, or Shaikh Ayaz and NM Danish and Tanwir Naqvi addressing hastily with someone. (As we have discussed in the paper).

52 Nathan Blanchard, "The Scatter Here Is Too Great," Washington Independent Review of Books, 2014 , http://www.washingtonindependentreviewofbooks.com/index.php/bookreview/thescatter-here-is-too-great. 


\section{References}

Ayaz, Shaikh. "The Heartache City." In Look at the City from Here: Karachi Writings, edited by Asif Farrukhi, 120-22. Karachi: Oxford University Press, 2012.

Blanchard, Nathan. “The Scatter Here Is Too Great.” Washington Independent Review of Books, 2014. http://www.washingtonindependentrevie wofbooks.com/index.php/bookreview/the-scatter-here-is-too-great.

Blom Hansen, Thomas, and Oskar Verkaaik. "Introduction - Urban Charisma: On Everyday Mythologies in the City." Critique of Anthropology 29, no. 1 (2009): 5-26. https://doi.org/10.1177/0308275X08101029.

Chaudhry, Lubna Nazir. "Reconstituting Selves in the Karachi Conflict: Mohajir Women Survivors and Structural Violence." Cultural Dynamics 16, no. 2-3 (2004): 259-90. https://doi.org/10.1177/0921374004047751.

Danish, N.M. "Lyari." In Look at the City from Here: Karachi Writings, edited by Asif Farrukhi, 186-89. Karachi: Oxford University Press, 2012.

Gayer, Laurent. Karachi: Ordered Disorder and the Struggle for the City. India: Harper Collins, 2014.

Gazdar, Haris, and Hussain Bux Mallah. "Informality and Political Violence in Karachi." Urban Studies 50, no. 15 (2013): 3099-3115. https://doi.org/10.1177/0042098013487778.

Graham, Stephen. Cities, War, and Terrorism: Towards an Urban Geopolitics. First. Malden: Blackwell Publishing, 2004. https://doi.org/10.1016/B978-012-374370-1/00004-5.

Hasan, Arif. "The Growth of a Metropolis." In Karachi: Megacity of Our Times, edited by Hamida Khuro and Anwer Mooraj, 171-95. Karachi: Oxford University Press, 1997.

Kaker, Sobia Ahmad. "Enclaves, Insecurity and Violence in Karachi." South Asian History and Culture 5, no. 1 (2014): 93-107. https://doi.org/10.1080/19472498.2013.863016. 
Kazi, Durriya. “ARTSPEAK: THE CITY AS AN IDEA.” Www.Dawn.Com, June 18, 2017. https://www.dawn.com/news/1339722.

———. "The City as a Canvas." www.dawn.com, 2017. https://www.dawn. com/news/1309996.

Khalique, Harris. "I'm Alive and So Is My City." In Look at the City from Here: Karachi Writings, edited by Asif Farrukhi, 243-44. Karachi: Oxford University Press, 2012.

Khuro, Haimda. "The Making of Colonial Port.” In Karachi: Megacity of Our Times, edited by Hamida Khuro and Anwer Mooraj, 1st., 27-61. Karachi: Oxfor University Press, 1997.

Low, Setha M. "The Anthropology of Cities: Imagining and Theorizing the City." Annual Review of Anthropology 25, no. 1 (1996): 383-409. https://doi.org/10.1146/annurev.anthro.25.1.383.

Rabe, Nate. "Ae Roshniyon Ke Shahar Bata." Lolly Pops dailylollyblog.wordpress.com, 2017. https://dailylollyblog.wordpress.com/2017/03/08/ae-roshniyon-keshahar-bata/.

Rehman, Saeed Ur. "I Imagine and Write in a Locally Grounded Way: Bilal Tanweer.” Herald, 2018. https://herald.dawn.com/news/1154015.

Sahil, Zeeshan. "Granny's Theory." In Look at the City from Here: Karachi Writings, edited by Asif Farrukhi, 241-42. Karachi: Oxford University Press, 2012.

Shakir, Perveen. "Karachi." In Look at the City from Here: Karachi Writings, edited by Asif Farrukhi, 39. Karachi: Oxford University Press, 2012.

Tanweer, Bilal. The Scatter Here Is Too Great (EPub Edition). London: Harper Perennial, 2015. https://www.scribd.com/read/234028805/The-ScatterHere-Is-Too-Great\#n_search-menu_726946. 